\title{
CORPO EM FRESTA: UMA EXPERIÊNCIA DE EXTENSÃO EM TEMPOS DE CONFINAMENTO
}

Corpo em fresta: an extension experience in times of confinement

Corpo em fresta: una esperienza di estensione in tempi di confinamento

\author{
Vitória da Silva Bemvenuto ${ }^{1}$, Adrianne Ogêda Guedes ${ }^{2}$, Juliana de \\ Souza Ferreira ${ }^{3}$, Wallace Araujo de Oliveira ${ }^{4}$, Maria Antônia Sattamini \\ de Souza ${ }^{5}$
}

\section{RESUMO}

Neste artigo buscamos tratar de nossas experiências na pesquisa sobre o corpo, a arte e a educação, em especial reflexões acerca do Habitar-se: uma ação extensiva inaugurada por nós diante dos afastamentos impostos pela pandemia da COVID-19. Assim, o Habitar-se afirma nosso compromisso com a extensão universitária, ao criar pontes entre uma universidade pública brasileira e a sociedade em tempos de incertezas. Com o objetivo de articular os relatos dessa ação, bem como alargar nossas percepções acerca do vivido, nos debruçamos sobre a proposição "Corpo em fresta", da qual participamos como organizadoras e propositor. Junto de uma perspectiva estética de educação (DUARTE JR., 2000; PERISSÉ, 2009), acreditamos que esta é uma oportunidade potente de nos reinventarmos em nossas práticas num movimento de propor, planejar, viver, sentir e repensar o que foi vivido.

Palavras-chave: Educação estética; Habitar-se; Movimento; Pandemia COVID-19.

\footnotetext{
${ }^{1}$ Mestranda em educação na Universidade Federal do Estado do Rio de Janeiro (UNIRIO), professora de Yoga pela tradição de Krishnamacharya.

${ }^{2}$ Doutora em Educação pela Universidade Federal Fluminense (UFF), , Professora Associada da Universidade Federal do Estado do Rio de Janeiro.

${ }^{3}$ Graduanda em Pedagogia pela Universidade Federal do Estado do Rio de Janeiro (UNIRIO).

${ }^{4}$ Mestre e Doutorando em Psicologia Social pela Universidade do Estado do Rio de Janeiro (UERJ), Docente do Curso de Pós-Graduação em Educação Patrimonial, no Instituto de Pesquisa e Memória dos Pretos Novos (IPN).

${ }^{5}$ Graduanda em Pedagogia pela Universidade Federal do Estado do Rio de Janeiro (UNIRIO).
} 


\section{ABSTRACT}

In this article we look forward to addressing our experiences in the research about the body, art and education, in particular thoughts about Habitar-se: an extensive action created by us towards the social conditions imposed by the pandemic of COVID-19. On behalf of that, Habitar-se affirms our commitment to the academic extension, by creating bridges between a public brazilian university and society in times of uncertainty. Aiming to articulate the narratives of this action, as well as to widen our perceptions about what was lived, we leaned into the proposition "Corpo em fresta", in which we participated as organizers and proposer. Along with an aesthetic perspective of education (Duarte Jr., 2000; Perissé, 2009), we believe that this is a powerful opportunity to reinvent ourselves in our practices in a movement of: proposing; planning; living; feelling and rethinking what was lived.

Keywords: Aesthetic education; Habitar-se. Movement; COVID-19 pandemic;

\section{ASSTRATTO}

In questo articolo cerchiamo di trattare le nostre esperienze nella ricerca sul corpo, l'arte e l'educazione, in particolare le riflessioni su Habitar-se: un'azione di estensione inaugurata per noi di fronte all'allontanamento imposto dalla pandemia COVID-19. Così, Habitar-se afferma il nostro impegno per l'estensione dell'università, creando ponti tra un'università pubblica brasiliana e la società in tempi di incertezza. Con l'obiettivo di articolare le narrazioni di questa azione, così come di ampliare le nostre percezioni su ciò che è stato vissuto, ci siamo concentrati sulla proposta "Corpo em fresta", alla quale abbiamo partecipato come organizzatori e proponenti. Unitamente ad una prospettiva estetica dell'educazione (Duarte Jr., 2000; Perissé, 2009), crediamo che questa sia una potente opportunità per reinventarci nelle nostre pratiche in un movimento di: proporre; organizzare; vivere; sentire e ripensare quello che è stato vissuto.

Parole chiave: Educazione estética; Habitar-se; Movimento; Pandemia COVID-19. 


\section{ANCORAGEM: NO ENCONTRO, O CORPO ESTÁ AQUI}

Chegamos a esta escrita pela via do encontro. Talvez estejamos frente a um paradoxo: diante da pandemia que impõe o distanciamento entre os corpos, fizemos-nos grupo. Por meio de telas virtuais, câmeras de vídeo, microfones e cantos de casa, nossos corpos se aglomeraram e compuseram a ação de ensino, pesquisa e extensão que iniciou em 2020: o Habitar-se. Ao participarmos de sua criação (em abril de 2020), da intenção até sua terceira temporada (iniciada em março de 2021), aguçamos nossa atuação enquanto experimentadores de nós mesmos. Experimentações estas estimuladas pela forma que o Habitar-se assume: ser um espaço-tempo voltado às diferentes vivências corporais propostas por pesquisadores/as do Corpo, do Movimento, das Artes e da Educação. Os encontros são mediados por uma plataforma remota para reuniões e vêm, no decorrer de suas temporadas, se transformando.

Assim, dispusemos nossas lunetas a fim de ampliar pensares e sentires a respeito do Habitar-se, compreendendo-o como um recurso sensível para nos mantermos ativos e em relação em tempos de pandemia. Para isso, escolhemos nos debruçar sobre a experiência "Corpo em fresta", na qual as quatro autoras e o autor que aqui se reúnem atuaram, respectivamente, enquanto participantes-organizadoras e propositor.

O Habitar-se é uma ação extensiva inaugurada em abril de 2020, com a intenção de afinar a conexão entre uma universidade pública brasileira e a sociedade nesses tempos de incertezas. Ele está vinculado a um Projeto de pesquisa, ensino e extensão, no qual atuamos e que acolhe e dá sustento a várias ações do nosso Grupo de Pesquisa - o FRESTAS (Formação e Ressignificação do Educador: Saberes, Troca, Arte e Sentidos). O grupo é composto por integrantes com distintos papéis: coordenadora, bolsistas de ensino, extensão, mestrado em Educação e pesquisador voluntário. O FRESTAS está ligado ao NiNA - Núcleo Infâncias, Natureza e Arte, junto a mais dois grupos de pesquisa, e está vinculado à Universidade Federal do Estado do Rio de Janeiro - UNIRIO.

"Corpo em fresta" foi uma das 21 proposições vivenciadas no Habitar-se em 2020, sendo uma das experiências que afinaram nossos laços de parceria. Pela afinidade que desenvolvemos, o propositor se integrou oficialmente ao nosso Grupo, em meio à pandemia, e agora, juntos, compomos este artigo com o objetivo de articular os relatos dessa ação de extensão, bem como de ampliar nossas percepções acerca do que foi vivido neste encontro. Acreditamos que esta é uma oportunidade potente de nos reinventarmos em nossas práticas, num movimento de propor, planejar, viver, sentir e repensar.

Inspirados em Larrosa (2002), temos a experiência como algo que nos passa e conecta e, 
então, nos guiamos por ela e pelos disparadores que traz consigo. Assim, somos, aqui, sujeitos da experiência, nos propondo a ser um lugar de pouso aos acontecimentos. Nesse sentido, escolhemos tecer esta escrita nos colocando enquanto territórios de passagem: "algo como uma superfície sensível que aquilo que acontece afeta de algum modo, produz alguns afetos, inscreve algumas marcas, deixa alguns vestígios, alguns efeitos" (LARROSA, 2002, p. 24).

Pelas linhas da experiência, evidenciamos nesta costura-texto nossas inspirações e as concepções práticas-teóricas que abraçamos no FRESTAS. Apontamos também o pano de fundo no qual nossas ações se desenvolvem - a pandemia do COVID-19 - entendendo que é necessário visibilizar as emergências que este momento escancara e, enquanto pesquisadores/as vinculados a uma universidade pública brasileira, afirmar nosso compromisso com a sociedade em acessibilizar os conhecimentos advindos da academia - vocação da extensão universitária. Assim, apresentamos o Habitar-se e o Projeto Corpo, Arte e Natureza: Investigando metodologias na formação de professores. Continuamos a costura partilhando as experiências com a proposição "Corpo em fresta", na qual o propositor tece suas palavras na primeira pessoa do singular e, junto dele, articulamos as reflexões acerca desse acontecimento. Arrematando, trazemos nossas sensações e percepções neste artigo.

\section{CORPOS QUE SE EXPANDEM NA PANDEMIA}

Nossas investigações e ações extensivas estão baseadas na dimensão estética da Educação e, mais especificamente, da formação docente. Assim, interessado nos aspectos sensíveis dos processos formativos, o nosso Grupo de Pesquisa se referencia nos fundamentos da Educação Estética (DUARTE JR., 2000; PERISSÉ; 2009) e em suas empreitadas e está comprometido a se manter atento aos acontecimentos, e não somente olhá-los de maneira genérica como simples conceitos. Compreende que voltar-se à Estética da Educação é dedicar-se a um processo de "sentir a si próprio e ao mundo num todo integrado" (DUARTE JR., 2000, p. 15).

Desta maneira, junto, especialmente, a Duarte Jr. (2000), nos colocamos disponíveis para que as questões se revelem enquanto partes "vivas" de nosso universo, como recursos à educação de nossa sensibilidade, nutrindo "um desenvolvimento de nossos sentidos e desse sentimento de que fazemos parte de um mundo significativo, com o qual estamos em simbiose" (DUARTE JR., 2000, p. 198).

Além disso, nossas práticas são costuradas de modo a juntarmos ensino, pesquisa e extensão, 
o tripé da universidade pública. Cuidamos para que nossos conceitos, escritas e falas estejam no mundo enquanto ponte entre a universidade e a experiência vivida, de modo que a teoria e a prática sejam sentidas como ações interdependentes, irmãs, que para existir precisam dialogar. Nesse sentido, evitamos caminhos que optem pelo "rompimento entre" (FREIRE; NOGUEIRA, 2020, p. 56) prática-teoria, que apartam o saber do ato de fazer. Na contramão desta separação, firmamos nossas iniciativas nesse tripé que sustenta a universidade através da compreensão de que as teorias estudadas devem estar imbricadas com o que vivemos na relação com/no mundo, e, num processo recursivo, o que produzimos nos fornece elementos para avançarmos em nossos conhecimentos e pesquisas.

Conectados às vivências e aos sujeitos com os quais cocriamos nossos projetos, sentimos nossas ações entrelaçadas com o saber do corpo, do mundo e dos demais seres da natureza (DUARTE JR., 2000). Desse modo, percebemos, com a Educação Estética, o quanto nossos corpos conhecem o mundo de forma integrada e, assim, construímos conceitos e esquemas sobre ele por meio das sensibilidades, compreendendo que

\footnotetext{
emprestar sentido - ao mundo — depende, sobretudo, de se estar atento ao sentido - àquilo que nosso corpo captou e interpretou no seu modo carnal. O sentir — vale dizer, o sentimento - manifesta-se, pois, como o solo de onde brotam as diversas ramificações da existência humana, existência que quer dizer, primordialmente "ser com significação" (DUARTE JR., 2000, 136).
}

Em contato com o mundo, neste momento, sentimos nossos corpos, ações e reflexões atravessados pela pandemia do novo Coronavírus. Desde março de 2020, o corpo-a-corpo com outras pessoas, as trocas no chão dos espaços educativos que frequentávamos e as vivências que experimentávamos coletivamente foram suspensas. Fomos acionados a um recolhimento obrigatório, a um afastamento físico imprescindível e a uma revisão necessária e inadiável de nossas maneiras de ser e estar com outros seres e o mundo. O vírus do silêncio (KRENAK, 2020) vem, desde o ano passado, se alastrando nos espaços entre as pessoas, pelas conexões entre as cidades e perpassando cada canto por onde passa, fazendo saltar as veias do mundo (SANTOS, 2020).

Segundo o Centro de Pesquisa em Virologia da Faculdade de Ribeirão Preto (2020) , a COVID-19 é um vírus respiratório que surgiu no cruzamento entre uma espécie animal, doméstica ou 
silvestre, e o ser humano. Seu alastramento a nível pandêmico se deveu à adaptação que sofreu no organismo da primeira pessoa que entrou em contato com ele. Assim, pelo contato entre os humanos, foi adentrando os pulmões, circulando pela corrente sanguínea e levando aqueles que tiveram sua casa-corpo (VIANNA; CASTILHO, 2002) habitada por ele de seus espaços de convivência para os hospitais.

Instalada a pandemia, afirmou-se a necessidade do afastamento físico e, para os que puderam, da quarentena, possibilidade esta que, segundo Santos (2020), “é sempre discriminatória, mais difícil para uns grupos sociais do que para outros e impossível para um vasto grupo de cuidadores, cuja missão é tornar possível a quarentena ao conjunto da população" (SANTOS, 2020, p. 15). Já os que não tiveram o direito à quarentena, se expuseram (e seguem se expondo), dia a dia.

É importante perceber o quanto esse cenário pandêmico estabelece uma relação direta entre questões salutares e o sistema ininterrupto de produção capitalista que, como diz Foucault (1991), produz corpos dóceis: "politicamente limitados e produtivamente eficientes através de uma política das coerções que são um trabalho sobre o corpo, uma manipulação calculada de seus elementos, de seus gestos, de seus comportamentos" (FOUCAULT, 2020, p. 135).

Assim, nossos corpos, cotidianos e ações estão atravessados por uma crise sanitária, política, econômica e social. Corpo este que enxergamos como nossa casa, compreendendo que antes mesmo de morarmos em qualquer outro lugar no mundo, o corpo é a primeira casa que habitamos (CASTILHO; VIANA, 2002).

É por meio dele que vivemos em sociedade e, por essa experiência, aprendemos, desvendamos, sentimos e dedicamos sentidos aos saberes. O corpo é como o marco zero do mundo, o lugar que se conecta a todos os outros lugares (FOUCAULT, 2013). Ao dedicarmos atenção a este corpo que "corre, age, vive, deseja, deixa-se atravessar sem resistência por todas as minhas intenções" (FOUCAULT, 2013, p. 11), sentimos que é em torno dele que os acontecimentos se esparramam, cruzam, se dispõem, dispersam ou se aproximam. Essa casa primeira dá pulso às experiências no mundo, e é por meio dela que "sonho, falo, avanço-o, imagino, percebo as coisas em seu lugar e também as nego pelo poder indefinido das utopias que imagino" (FOUCAULT, 2013, p. 14).

Essas ideias envolvem o processo que percorremos para dar nome e forma ao Habitar-se. O

${ }^{1}$ Palestra intitulada “Corona virus: que virus é esse?” Realizada no Simpósio: Covid-19 que doença é essa? da Academia Nacional de Medicina. Evento online e ao-vivo que ocorreu no dia 09 de julho de 2020. 
verbo que o nomeia simboliza um movimento de percebermos nosso corpo para além de uma estrutura de ossos, músculos e órgãos úteis à manutenção do sistema capitalista de produção, e reconhecê-lo como nossa primeira residência e lugar que torna possível nossa manifestação no mundo. A ação extensiva Habitar-se deseja nos lembrar, por meio de experiências com práticas corporais proposta por pesquisadores/as das Artes, da Educação, do Corpo e do Movimento, que "cuidar do corpo é, pois, como a manutenção de uma casa. É bom abrir as janelas de vez em quando, deixar o ar circular, dar uma arejada" (CASTILHO; VIANA, 2002, p. 20).

É com este corpo que vivemos este momento histórico: que coloca em xeque as engrenagens do capital, o valor das quantidades em detrimento da qualidade e o apreço pelo lucro em lugar da vida. Um acontecimento que, ao mesmo tempo que chacoalha nosso chão, possibilita, enquanto crise - e, portanto, "situação-limite" (FREIRE, 2018) - criar maneiras outras de ser com o mundo, fortalecer presenças e organizar ações que nos aproximem dos “inéditos-viáveis" (FREIRE, 2018) que desejamos.

O inédito-viável significa a criação de capacidades, cumplicidades, condições e disposições que nos permitem transformar as utopias em realidade na história. Isso não significa que elas possam ser feitas hoje e agora totalmente, mas que podemos fazer hoje as mudanças mais profundas que sejam possíveis, graças às quais criaremos condições para que outras mudanças que não podemos fazer agora, sim sejam possíveis (JARA, 2020, p. 4).

É sobre este terreno, e interessados na relação entre corpo, educação e sociedade, que escolhemos permanecer em pesquisa ao perceber que neste momento se acirram enfrentamentos, dificuldades e questionamentos originários da nossa relação com o mundo, bem como se anunciam pistas capazes de nutrir reflexões sobre nossos campos de atuação e fortalecem nosso comprometimento como cocriadores de uma educação estética que também nos reconstitui. Assim, surgem novos encontros movidos por todos estes deslocamentos, como um alastramento do cuidado de si e do interesse na educação e na sociedade.

Nos apoiamos no cuidado de si enquanto uma ética da existência e não como uma forma de se manter sempre disposto e obediente às vontades dos modos de produção instituídos. Como nos sinaliza Foucault (2006): 
[...] na Antiguidade, a vontade de ser um sujeito moral, a busca de uma ética da existência eram principalmente um esforço para afirmar a sua liberdade e para dar a sua própria vida uma certa forma na qual era possível se reconhecer, ser reconhecido pelos outros e na qual a própria posteridade podia encontrar um exemplo [epiméleia heautoû]. [...] Da Antiguidade ao cristianismo, passa-se de uma moral que era essencialmente a busca de uma ética pessoal para uma moral como obediência a um sistema de regras [gnôthi seautón] (FOUCAULT, 2006, p. 289-290).

Assim, ancorados por esse cuidado de si e embasados pelo Projeto Corpo, Arte e Natureza: Investigando metodologias de formação de professores, nos dispusemos a continuar nutrindo a relação com as artes, o corpo e as sensibilidades no encontro com processos de formação docente (inicial e continuada), aprofundando reflexões, sentidos e experiências; reconhecendo que essas dimensões são indispensáveis ao ato de saber e à "construção de uma experiência formativa potente, que abra um espaço sensível, de canais de prazer com a vida e que sustente a experiência e a existência" (GUEDES, 2018, p. 3).

Esse Projeto, ao qual estamos integrados, tem como foco os/as estudantes do curso de Pedagogia da UNIRIO, demais professores/as e outras pessoas interessadas, externas à universidade, e se desenvolve pela metodologia de pesquisa-formação (LONGAREZI e SILVA, 2013), percurso este que se propõe a ser meio de superação de formas convencionais, muitas vezes colonizantes e objetificantes, de pesquisa e de formação. Nossos métodos de fazer buscam promover diálogos com a formação, considerando os/as pesquisadores/as e demais sujeitos envolvidos no processo enquanto pessoas inteiras - tendo a precaução metodológica de não apartar o corpo físico de suas subjetividades. Nesse sentido, compreendemos, em consonância a Longarezi e Silva (2013), a pesquisa como algo que aflora na realidade e em seu processo de acontecer, transforma os sujeitos e a própria pesquisa enquanto forma. Assim, as experiências formativas são nutrientes para as investigações do Grupo e para o florescimento de novas frestas de ação.

Inspirados, então, nas intenções com as quais mantemos e desenvolvemos o Projeto Corpo, Arte e Natureza, escolhemos alimentar o desejo de estarmos com os sujeitos com quem cocriamos nossas ações. Assim, estimulamo-nos a encontrar cumplicidades, a alargar condições para que o sonho da presença e do encontro seja possível. Dessa forma, inauguramos a ação extensiva Habitar-se e nossos corpos esparramaram-se durante a pandemia. 


\section{O HABITAR-SE VAI SE MOVENDO PELAS TELAS}

Sentíamos muita saudade dos espaços de encontro presenciais promovidos pelo Grupo na universidade, tanto nos encontros da pesquisa como também (e principalmente) no encontro com os estudantes do curso de Pedagogia da UNIRIO através do componente curricular obrigatório "Corpo e Movimento"2. Lá, também nos debruçávamos sobre a dimensão estética da educação através de metodologias teórico vivenciais, na qual o corpo cria conhecimento e recria a si mesmo através dos encontros com as turmas.

Diante da necessidade de distanciamento social, combinamos - enquanto equipe atuante nesse componente curricular obrigatório como professora responsável, monitoras bolsistas e estagiária docente - de nos encontrarmos, uma vez por semana, virtualmente, para conversar e nos mover por meio de uma vivência de corpo inteiro. Experimentamos, assim, nosso primeiro encontro com o movimento mediado pelas telas. Um encontro acolhedor e inspirador: a partir dele, nutrimos a ideia de que esse espaço-tempo de experimentações fosse habitado por outras gentes. Passamos, então, a convidar pesquisadores/as, professores/as e artistas para serem propositores das experiências que transformaram o Habitar-se em um espaço voltado ao contato consigo, com o outro, com o movimento, com o corpo e com as artes; uma ação pública, gratuita, que não solicita nenhuma experiência prévia com qualquer prática corporal. Assim, começamos a divulgar os encontros, primeiramente, aos estudantes de "Corpo e Movimento" para que pudéssemos continuar nutrindo a relação com eles.

Aos poucos, o Habitar-se foi se transformando, assumindo o corpo de projeto de extensão universitária: foi se expandindo para receber pessoas de diversos lugares do Brasil, de outras universidades, com diferentes ocupações (dentre elas professores/as da rede, em especial os membros do Sindicato dos Professores do Município do Rio de Janeiro e Região, o SINPRO Rio).

Atualmente, a equipe organizadora do Habitar-se é composta por nossa orientadora, duas graduandas de Pedagogia como bolsistas (de Extensão e de Iniciação Científica), três mestrandas em Educação e um pesquisador voluntário. Juntos, nos articulamos para possibilitar que cada encontro fosse recheado por uma vivência inédita para todos/todas os/as participantes, inclusive para nós - a equipe -, nos provocando a repensar e reinventar este espaço diariamente. O Habitar-se também se sustenta com as parcerias que firmamos com as/os propositoras/res e as demais pessoas que o experimentam.

\footnotetext{
${ }^{2}$ Componente curricular obrigatório do curso de Pedagogia da UNIRIO.

${ }^{3}$ Vivência proposta por nossa coordenadora, uma das autoras deste artigo, e direcionada, neste primeiro momento, para os/as integrantes do grupo.
} 
Neste sentido, essa ação extensiva vem se modificando desde sua inauguração (em abril de 2020). Como organizadores, mantemos nossos corpos porosos para escutar, enxergar e refletir a respeito do que nos acontece. A estrutura que a ação assume colabora para a contínua atenção aos detalhes: ao longo dos 60 minutos que percorremos juntos às quintas-feiras, a partir das 18 horas e 30 minutos, passamos por uma apresentação inicial do Habitar-se, que tem uma breve duração (10 minutos), para que o tempo da experiência corporal se estenda pelo tempo cronológico de maneira mais generosa (40 minutos), e finalizamos com o espaço de partilha em que os/as participantes contam sobre seus sentires a respeito da vivência e tecemos uma conversa por meio desses afetamentos.

Esses momentos de troca ao final vêm contribuindo para que o Habitar-se se transforme, tendo em vista que recebemos feedbacks e sugestões para o melhoramento e manutenção desse nosso espaço. Deste modo, de maio a julho de 2020, vivemos a primeira temporada: nos encontramos semanalmente (às quintas-feiras) e, durante 1 hora, experimentamos práticas corporais com profissionais de diferentes áreas (Técnica de Alexander, Fisioterapia, Yoga, Educação Somática, Dança, Artes etc.). Percorremos um caminho desafiador e tivemos que mudar diversas vezes as plataformas de reuniões que usávamos para os encontros, tendo em vista que estávamos descobrindo as possibilidades, instabilidades e potencialidades que o meio virtual nos oferecia: a internet caía, a imagem travava e o áudio cortava, mas, ainda assim, continuávamos lá, firmes e suaves, acreditando que os atravessamentos nos ensinam e estimulam reinvenções.

Assim, ao nos aproximarmos do fim da primeira temporada com as práticas corporais semanais, abrimos uma nova fresta: encontrar com alguns/as dos/das propositores/as e participantes para conversarmos e refletirmos coletivamente a respeito das experiências que vivemos. Desta maneira, inauguramos no final de julho de 2020 o "Habitar-se: experimentando a presença e o cuidado". Vivemos essas conversas, também abertas ao público e gratuitas, em formato de lives, durantes algumas segundas-feiras por meio do perfil do Núcleo Infâncias, Natureza e Arte na rede social Instagram. Foram 8 encontros (julho-setembro) que nos nutriram de desejos e nos incentivaram a continuar.

Após, passamos um mês de férias coletivas do grupo de pesquisa e permanecemos, ao longo deste tempo, cuidando de nossas intenções para que, em outubro, pudéssemos retomar nossas empreitadas. E assim aconteceu: em primeiro de outubro de 2020, teve início a segunda temporada do Habitar-se, que foi inaugurada por um pesquisador, bailarino, artista e professor, agora também tecelão deste artigo por meio da proposição "Corpo em fresta". Ela alargou o espaço para a nova dinâmica que nossa ação extensiva assumia: os encontros se manteriam às quintas-feiras, com du- 
ração de 1 hora, mas acontecendo quinzenalmente. Esta mudança visou acolher as necessidades de um maior espaço e tempo fora das telas, devido ao volume de trabalhos e afazeres que nós, pesquisadores/as, e os/as demais participantes, precisávamos assumir e os retornos que as pessoas faziam às atividades cotidianas (principalmente o trabalho) fora de casa.

Neste sentido, propusemos intercalar duas experiências: em uma quinta-feira, estaríamos nos movendo coletivamente por meio das telas e, na outra, cada participante enviaria um registro autoral construído a partir dos sentires com a vivência corporal daquele encontro. Disparávamos, então, após cada prática, um e-mail convidando aquelas/es presentes no Habitar-se daquela semana a compor esse registro, partilhar suas reflexões e entrar em contato com os materiais que o/a propositor/a havia sugerido, a fim de ampliar o contato com a vivência experimentada. Além disso, podíamos continuar mantendo a relação com os participantes até a próxima quinta-feira, em que estaríamos juntas/os, e, com esses registros, ampliaríamos os materiais a respeito desta ação extensiva, de ensino e pesquisa. Essa invenção também se mostrou desafiante: nem todos/todas enviavam os registros, muitos por não conseguirem anexar o registro ao corpo do e-mail, mas as partilhas que recebemos nos inspiraram a permanecer em ação.

Desta maneira, navegamos pela segunda temporada até dezembro de 2020. Experimentamos diversas proposições e, agora, adentramos a terceira temporada do Habitar-se, na qual experimentamos uma outra configuração. Interessadas em ampliar o tempo de partilha e reflexões coletivas, desde 18 de março de 2021 os encontros passaram a ter 1 hora e 30 minutos, de maneira que os novos 30 minutos fossem dedicados a criar um registro coletivo, de escuta e narrativa de como aquelas experiências chegaram aos corpos que estavam ali presentes.

Nessa trajetória, temos encontrado alguns desafios, dentre eles: dificuldades com a plataforma virtual em que ocorrem os encontros; a organização de datas e horários viáveis para todos os envolvidos, de maneira que pudesse oportunizar uma regularidade aos encontros; e a preocupação sobre como receberíamos um feedback dos/das participantes acerca do que foi vivido. Uma de nossas prioridades é pensar de que maneira esses registros e impressões do que foi vivido estariam nos ajudando a reinventar o Habitar-se, garantindo, assim, a sua continuidade. Acreditamos que através dessa articulação entre diferentes narrativas das experiências (pelos participantes e por nós) e o que sentimos em nossas trocas enquanto grupo de pesquisa (acerca do que pode ter funcionado e o que pode melhorar) se descortinam pistas de como podemos aprimorar a ação em si.

Dessa maneira, compreendemos o Habitar-se como uma ação extensiva que a cada encontro se fortifica e floresce, nos ofertando novas possibilidades de atuação. Passo a passo, vamos com- 
pondo uma metodologia que se compromete com a continuidade, que a cada temporada se reinventa sem perder de vista seu objetivo: criar espaços de encontros e presenças na pandemia através de uma perspectiva estética da educação.

\title{
CORPO EM FRESTA: RELATOS E DIÁLOGOS COM O PROPO- SITOR
}

Escrevo do lugar de propositor, no qual não me vejo neutro, tampouco distanciado. As telas em movimento me situam na aposta de uma habitação ainda maior nesse espaço-tempo chamado vida. E, se há vida, de que forma com-viver se não habitando-nos coletivamente e nos cuidando no desafio de estarmos e sermos corpo?

\begin{abstract}
De onde sou e estou, ouço uma canção recentemente composta e lançada por Adriana Calcanhoto via Spotify, uma inspiração urgente em que compartilha de criatividade e reflexão durante sua rotina pandêmica. Eis que a arte surge e insurge nessa voz me chamando a atenção e criando ecos: "o que temos são janelas". Casas, olhos, corpos, telas, computadores, TVs, celulares... De onde afinal nos notamos? De que modo abro e me abro para o encontro com tudo o que é vida e se torna porta-voz de desafios e incertezas? Sou e estou vivo a ponto de fingir ou não ver? Em que medida estou e sou visto no vasto universo de aplicativos, redes supostamente sociais e algoritmos? Não tenho respostas, sigo me abrindo, reexistindo no desafio do confinamento (OLIVEIRA, 2021, p. 211-212).
\end{abstract}

Abrir o corpo para, então, propor respiros foi uma investigação compartilhada no encontro de 01/10/2020, via plataforma virtual. Honrado com o convite que recebi do Grupo FRESTAS, refiz meu percurso de contato com o Habitar-se, uma vez que fui participante de vários encontros propostos. Para compor a vivência, me inclinei a pensar em torno da palavra "fresta" que, em sua definição, trata-se de um substantivo feminino, referindo-se a uma abertura estreita, uma fenda, ou quem sabe até a uma rachadura. Tantas eram as reflexões que me pus então a rascunhar um tema.

A proposta dessa aula temática foi experimentar o que talvez não caiba num nome, mas é vivo em sua indefinição. Propus a investigação da palavra fresta encarnada na materialidade do corpo, possibilitando, assim, a extensão inexplorada do seu significado. Eis que brotaram algumas 
indagações: no desafio de estar e ser corpo, de que forma nos encobrimos e vemos nossas frestas? As entenderíamos como convite a passagens ou ventilações? Como nos lemos ou percebemos entre frestas? Estaríamos dispostos à ampliação dessas estreitas aberturas?

Nessas perguntas disparadoras supracitadas, convidei a todos a me acompanhar numa pesquisa acerca de um CORPO EM FRESTA. Tanto ocorreu ao longo do encontro que suor, emoção, saudade, vontade, desejo, necessidade e tantas outras inomináveis coisas emergiram deste corpo que se uniu a telas e pôde, assim, escancarar as frestas, colocar de lado suas cortinas e deixar ventar muitas possibilidades de existirmos, de resistirmos e prosseguirmos.

A intimidade com nossos corpos e espaços trouxe o mapeamento de realidades que puderam ser compartilhadas ao final do encontro, no após do encontro e nos desdobramentos do encontro. Sim! Encontro: consigo, comigo, em coletivo e irmanados nas muitas cenas que em mosaico puderam se movimentar e deixar clarear algumas sombras de insegurança do atual tempo. Partindo, então, do tempo próprio da experiência, dos espaços e corpos visitados entre telas, alguns relatos nos foram compartilhados e, não diferente de tudo o que reverberou e ainda reverbera em memórias, compartilho também aqui:

Comecei a aula deitada, cansada e estado mental tenso. Durante o exercício de buscar frestas, de entrar em contato com meu interior, fui me movendo, dançando, assumindo as sombras que se espalham a partir da fresta no meu coração - lugar escolhido para iniciar o exercício e fazendo as pazes com elas, convidando-as a dançar. Terminei a aula relaxada, leve e animada. Obrigada pela oportunidade! (Corpo em fresta participante 1)

A liberdade de partir de um estado físico ou de um lugar qualquer era uma premissa do encontro, onde movimento ou não movimento eram tão possíveis quanto admissíveis. Afinal, de nossos espaços particulares, reconhecer alguns limites para a tentativa de ultrapassá-los dependia da articulação de muitos momentos e espaços que se fundiam num só.

Nesse período de pandemia decidi dar um passo adiante: fazer terapia pela primeira vez. E durante esse processo decidi fazer da escrita um re- 
fúgio para expressar-me e registrar meu processo, sendo assim, na terceira semana de terapia escrevi “(Me) Habitar (-se)”, mas ainda não sabia por onde e nem como começar e deixei a palavra suspensa no ar entre uma semana e outra.

Foi quando me lembrei de um conto que escrevi no começo do ano para a disciplina de Corpo e Movimento, nesse texto fiz minhas palavras se derramarem e dizerem tanto sobre mim que nem percebi e em um parágrafo específico deixei claro o que queria e precisava:

"E quando estiver afundando dentro de você mesma, pare. E quando se sentir sufocada, respire mais profundamente. E quando sentir que você está perdida, habite-se. É hora de reconectar-se com seu eu e voltar para casa. Seu corpo esteve com você durante todas as batalhas, e aguentou o peso bom e ruim das lágrimas e dos sorrisos. Seu corpo, foi uma muralha que suportou muito e teve momentos que nem conseguia alcançar a velocidade dos seus pensamentos, mas ele nunca te abandonou."

Nesta nova etapa, ainda são muitas as palavras e sentimentos perdidos dentro de mim, às vezes, eles decidem fazer uma reunião e dela sai uma frase, uma estrofe ou algo mais extenso e elaborado. No entanto, para quem ainda está aprendendo a lidar com o termo - inibição afetiva - os passos para habitar- me e expressar-se são devagares e tímidos (eles ainda estão aprendendo a andar sozinhos). Sendo assim, sem saber por onde começar ou terminar, deixarei fragmentos das palavras que se juntaram dentro de mim:

Um ato de coragem

Para habitar-me

Foi fazer terapia

Neste ato esgueirei-me por uma fresta

Ainda sem nome

Mas a identifico como alma

Ou janela, se preferir. 
Deixei o silêncio descansar mais um pouco

Pois existia muito barulho em mim

E então, decidi chamar eles pra dançar

Rodopiei até esquecer que os cabelos estavam bagunçados

Os pés descalços

E um sorriso largo se formava em mim

(Corpo em fresta participante 2)

Das palavras e percepções que se derramam, podemos notar os diversos atravessamentos de um corpo no qual habitar-se é também inquietar-se. Percebemos aqui uma forte tendência de nossa ação a abrir frestas ao cuidado de si no cotidiano, que, por sua vez, se demonstra como uma ferramenta estética potente para uma vida que se repensa a cada dia, estranhando suas rotinas e analisando a si mesma:

[...] o cuidado de si, quando articulado a questões éticas e de liberdade dos sujeitos, pode tornar-se ferramenta de enfrentamento a práticas e discursos políticos que recheiam nosso cotidiano de dispositivos de verdade e de biopoder, e têm como principal objetivo manter controladas as práticas dos sujeitos, restringindo suas vidas a escolhas (ou falsas liberdades) "previamente demarcadas", minando passo a passo suas vontades de sentirem-se livres - o que caracteriza, assim, um processo engessador de práticas e saberes, e normalizador da vida subjetiva dos indivíduos (GOMES, 2013 apud GOMES; FERRERI; LEMOS, 2018, p. 190).

$\mathrm{Na}$ revisão dos afetos que apontam suas direções e seus motivos, formar-se constantemente nas pistas que o próprio corpo dá através desse cuidado de si nos comunica os esconderijos íntimos que se tornam parte de um registro.

Eu achei o encontro e a condução incríveis, mas não me sinto pronto 
para continuar porque me senti muito desconfortável em meu próprio corpo durante a prática. Ainda não me sinto pronto para abrir as frestas desse encontro comigo mesmo. Mas muito obrigado pelo convite e pela experiência! (Corpo em fresta participante 3)

Curioso é pensar no quanto a prontidão nos é cobrada ou convocada. Com o relato do “Corpo em fresta participante 3" me deparo com os limites comunicados frente à minha proposição. Não se sentir pronto e poder admitir isso no refúgio do próprio espaço e sem a câmera ligada fez a mim um convite para a reflexão de nossas práticas. Longe de qualquer obrigatoriedade, o desconforto era também bem-vindo, junto a todo e qualquer limite que nos lubrificasse uma noção outra de participação.

Há muito tempo submetidos a enquadramentos e normativas, atualmente uma pandemia nos acomete ao distanciamento físico, o que em muito afeta nossas perspectivas sociais. Segundo Foucault (2020), “estamos na sociedade do professor-juiz, do médico-juiz, do educador-juiz, do 'assistente-social'-juiz; todos fazem reinar a universalidade do normativo; e cada um no ponto em que se encontra, aí submete o corpo, os gestos, os comportamentos, as condutas, as aptidões, os desempenhos" (FOUCAULT, 2020, p. 299).

Julgamentos de variadas ordens nos coabitam. Portanto, que maneiras outras haveriam de nos habitarmos em diferentes direções e perspectivas? O que entendemos por cuidado do próprio indivíduo ou da relação em coletivo? Nos questionando, identificamos inspirações para propostas por onde as avaliações enrijecidas pudessem se dissolver, nos encontrando numa outra forma de compor encontros, reflexões e cuidados.

O encontro foi lindo, potente. Esperava encontrar um grupo que iria discutir sobre a teoria de como estamos desconectados com o nosso corpo e para minha surpresa, pudemos vivenciar a escuta desse corpo que à todo momento pede para ser habitado. Amei!!! (Corpo em fresta participante 4)

O reconhecimento de potência que residiu numa proposta como a do Corpo em Frestas trouxe implicadas expectativas do formato de encontro, onde uma teoria fosse a única direção. Mas não. A prática nos permitiu habitar diferentes implicações, e que a posteriori inspirou articulações, diá- 
logos e cultivos de um chão teórico como os que propomos no presente estudo. Do que se esperava ao que se encontrou, as frestas que, em parte corpos e em parte telas, nutriram a experiência nos faziam escutar, ver, suar e entender cada necessidade social, emotiva, cultural ou psicológica que permeava diferentes corporeidades.

O encontro possibilitou deixar o meu corpo livre que, de tanto poder relaxar, acabei por cair no sono, mas foi uma boa sensação, pois senti-me livre de poder verdadeiramente relaxar. (Corpo em fresta participante 5)

A liberdade de poder ser, estar ou sentir nem sempre é experimentada diante de padrões, conveniências ou quaisquer forças opressoras em sociedade. Poder cair no sono e desfrutar da pausa enquanto outros se movimentavam na proposição foi a contramão do "tem que ser assim". Não havia qualquer imposição entre nós, apenas estímulos. Quando aqui escrevo nós, estou me afirmando enquanto propositor tão implicado quanto qualquer outro corpo em fresta participante. As distâncias eram sim físicas, mas foram de alguma forma encurtadas na instrumentalização de tudo o que se deu e pude, juntamente, experimentar, já que "o experimentador, longe de se manter em segundo plano, envolve-se: envolve seu corpo, envolve seu conhecimento, sua responsabilidade e seu futuro. A prática de saber se transformou numa prática de importar-se" (DESPRET, 2004, p. 130).

Tratava-se de uma entrega sem qualquer negociação ou regra. Todos eram bem-vindos e livres para abrirem ou não suas câmeras e se revelarem de acordo com seus momentos e suas próprias percepções. Afinal, conforme Neil Gaiman (2016, p. 142), "só podemos acreditar em nossos sentidos: os instrumentos que usamos para perceber o mundo, nossa visão, nosso toque, nossa memória. Se eles mentem para nós, nada será confiável. E, mesmo se não acreditarmos neles, não há como seguir nenhum outro caminho além da estrada que nossos sentidos nos revelam; e devemos percorrer essa estrada até o fim".

"Metade de mim é abrigo mas a outra metade é cansaço". Metade de mim no encontro, sentindo a música e as questões trazidas e a outra metade nos que não conseguiram chegar junto, em quem teve dificuldade de entrar e ainda na batalha travada com o computador, a internet e a plataforma utilizada. "Estamos fazendo o que é possível nesse momento louco..." Tento me contentar com essa realidade, mas sinto muita falta 
do presencial. Sentir as respirações da turma em sala numa sexta feira à noite é insubstituível.

“Tem excesso nesse corpo? Tem resquício desse home office, dessa tela? O que pode transbordar nesse corpo?"

Compartilhamos o calor com pessoas em quadradinhos mesmo, pois era o que dava pra fazer, e foi muito gostoso estar ali. Ver aos pouquinhos os rostos sorrindo, os corpos dançando e o que me permitia a plataforma enquanto eu gravava o encontro para revisitarmos ele posteriormente. Por conta disso o propositor ficava num quadradão ocupando a tela quase toda e só de vez em quando apareciam uns rostinhos que eu sabia que estavam ali, embaixo dele, bem pequenininhos. Acho que quem não teve de gravar teve mais chance de ver as pessoas. Senti muita falta disso.

Zumzumzum, barulhos, tarefas nossas, nessa hora eu fiquei tão nervosa! Pois quando alguém tava perdendo o sinal e eu tinha que tentar assumir a música, foi bem caótico compartilhei tela, travei meu som, travei o computador com tanto zumzumzum.

"Barulho demais", nos foi dito enquanto eu tentava fazer as pazes com o Spotify. "E se amigo é repartir, eles também nos convocam ao cuidado, eles dão aquele alerta que nem sempre a gente percebe." e o meu zap apitando no meio do compartilhamento do som.

Questões técnicas à parte, foi um encontro maravilhoso, pude mergulhar na prática e sentir os participantes desejosos de estar ali, acho que isso é muito especial pra nós, por não ser nada obrigatório (tipo um componente curricular obrigatório) só fica quem tá afim mesmo e disposto a se mergulhar na proposta e isso é lindo. (Corpo em fresta participante 6)

Questões de variadas ordens compuseram o cenário virtual. E, como toda cena possui seus bastidores, a tecnologia atuava convocando ajustes, preocupações e o desafio assumido do não domínio. O relato supracitado localiza aqui a noção dos esforços para que, além de dar certo, fazer possíveis. Uso oportunamente em plural para tentar dimensionar o que transbordava os limites não apenas corporais, mas do previsto, do seguro, do roteirizado. Nada estava dado, mas se compondo e 
repercutindo até o momento em que aqui escrevo. Não menos importante, o chat foi também espaço no qual nos habitamos e encontramos para finalizar a proposição, considerando que ele se fez fresta para a circularidade de afetações por meio de palavras, deixando fluir livremente o que se quisesse expressar:

\footnotetext{
"Sensacional! Estava precisando muito. Corpo cheio de tensão e de medo".

"Temos que dançar todos os dias. Obrigada por me lembrar disso".

“Estava precisando!!!"”
}

"Foi ótimo. Levantou meu astral e me senti mais em paz comigo mesma!"

"Frestas da alma que transbordam no corpo".

“Obrigada!!! Trouxe uma vivacidade!!! Estou sentida, empolgada e encantada".

"Parabéns a todas e todos. Sou professora universitária e tenho projeto de dança também. Fico feliz de ver mais projetos assim com corpo e afeto. Falo aqui de Curitiba. Entrarei em contato para, quem sabe, fazermos trocas. Agradeço" (Corpo em fresta participante 7)

\section{ARREMATE PELA COMPOSIÇÃO DAS TELAS}

Chegamos aqui com o intuito de ampliar pensares e sentires a respeito do Habitar-se. Performamos este artigo enquanto sujeitos da experiência, nos colocando porosos aos afetamentos e estímulos que a proposição "Corpo em fresta" nos gerou. Percebemos que, à medida que o Habitar-se se faz enquanto um espaço-tempo aos corpos, é possível, mesmo diante das telas, cocriar e inventar caminhos outros para estarmos juntos: em pesquisa, em formação, em sociedade e em prática. Assim, essa ação extensiva tem nos possibilitado produzir presenças, estabelecer novas redes e contatos, tão necessários neste momento de instabilidades políticas, sanitárias e sociais.

Neste sentido, o Habitar-se continua ganhando corpo pelos corpos de muitas gentes: participantes, propositores/as, equipe organizadora e demais apoiadores/as. Com os corações abertos, escutas ampliadas e disponíveis adentramos, no mês de março, nossa terceira temporada, acreditando que no encontro compomos um espaço coletivo onde a universidade pública, gratuita e de qualidade 
re-existe diante do que nos atravessa.

Vamos, assim, compondo nossas costuras pelas telas, vivendo a experiência do Habitar-se de corpo inteiro e presentes, apesar das distâncias e de todas as dificuldades tecnológicas. Nossa participação em "Corpo em fresta" toma outras proporções quando nos debruçamos sobre os relatos de cada pessoa que compôs esse encontro: nos deparamos com disponibilidades, interesses, dificuldades, deslocamentos, cuidados de si e estéticas. Numa via de mão dupla, atravessamos as experiências dos/as participantes pelas telas e também somos atravessados pelas reverberações do que construímos em conjunto. É através das releituras que fazemos sobre o ocorrido e das pistas que esse movimento nos dá que vamos traçando novos caminhos para repensar e habitar o projeto.

Por falar em criar com o que atravessa, escolhemos finalizar nossa escrita com um trabalho artístico produzido por uma das autoras deste artigo, acreditando que o sentir impacta nossas percepções e transborda saberes.

Figura 1: Corpos pelas frestas: borrando linhas, telas e fluxos - Colagem inspirada na proposição "Corpo em fresta"

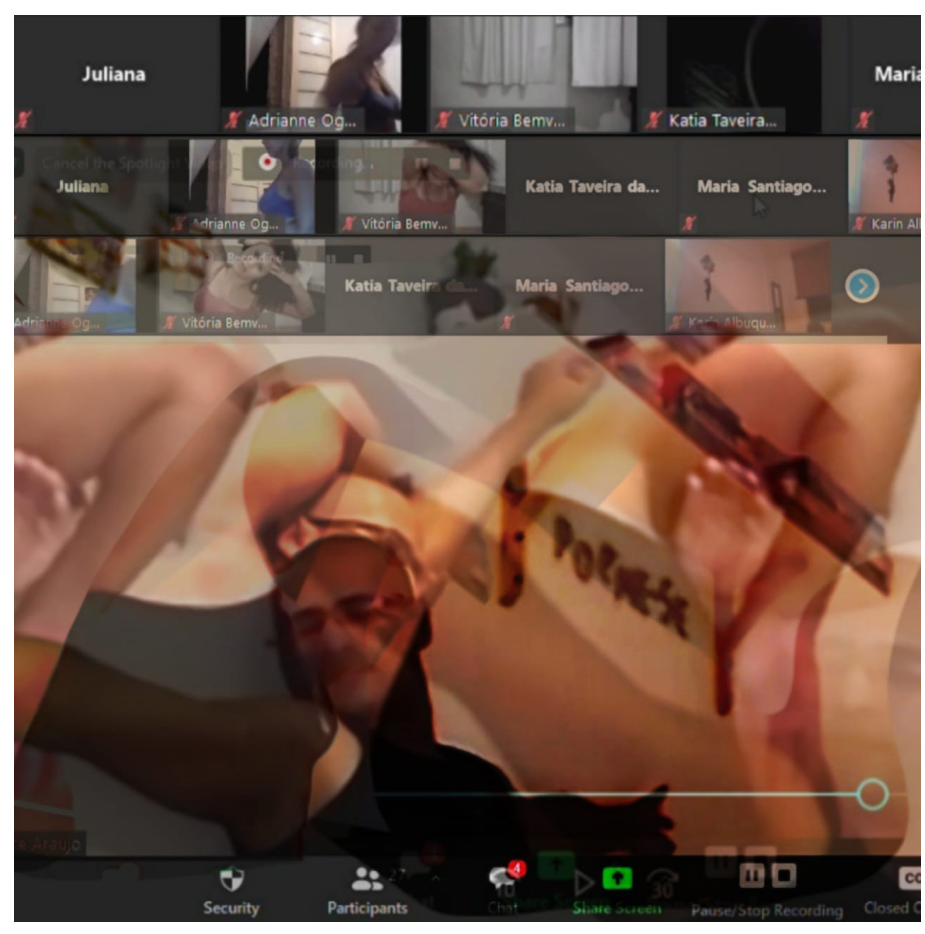

Fonte: Acervo da Pesquisa

\footnotetext{
Evidenciamos que durante a inscrição para participação do Habitar-se, todas/todos os/as se tornam cientes, por meio do formulário que preenchem, que os encontros serão gravados e que tanto a gravação quanto os registros produzidos a partir das experiências são considerados parte do acervo de pesquisa do FRESTAS. Assim, todos/todas os/as participantes, quando se inscrevem, concordam e autorizam - através da aceitação do Termo de Responsabilidade - a veiculação de suas imagens, vozes e depoimentos em qualquer meio de comunicação para fins didáticos, de pesquisa e divulgação de conhecimento científico sem quaisquer ônus e restrições.
} 
Essa colagem transbordou do movimento de re-viver, re-sentir e de se re-afetar por "Corpo em fresta". A partir da gravação que tínhamos da proposição, printamos essas imagens a fim de criarmos um outro registro do vivido. Uma foto tirada da gravação da experiência que cocriamos com nossos corpos. As dobras, as linhas, os movimentos, as telas dentro da tela, os ícones próprios da plataforma virtual na qual o Habitar-se acontece e alguns/algumas dos/das participantes compõem este transbordamento. Os corpos se expressam sobre o plano de fundo remoto: se recolhem, se expandem e produzem novos borrões. Por meio dos retângulos, das tecnologias computadorizadas, da música que extravasa as caixas de som dos equipamentos e das imagens que chegam aos nossos olhos através dos vidros, construímos nosso coletivo. No fluxo, observamos um embaçamento: algo que nos atrapalha enxergar com clareza, com certeza e com detalhes milimétricos os gestos. A luz borra os desenhos perfeitos, ressaltando os desafios que encontramos nessas experiências virtuais: a luminosidade da tela dificulta a visão, o movimento trava quando a internet cai e os sons do ambiente em que estamos atravessam nossas falas, mas o corpo transpassa esses obstáculos e a deficiência de nitidez passa a simbolizar novos desenhos metodológicos, criando outras camadas dessa experiência. Assim, a baixa resolução não é desleixo e nem proposital, é acontecimental.

\section{REFERÊNCIAS}

DESPRET, Vinciane. The body we care for: figures of Anthropo-zoo-genesis. Body \& Society, v. 10, n. 2-3, p. 111-134, 2004.

DUARTE JUNIOR, João Francisco. O sentido dos sentidos: a educação (do) sensível. 2000. $234 f$. Tese (Doutorado em Educação) - Universidade Estadual de Campinas, Campinas, 2000.

FREIRE, Paulo. Pedagogia da esperança: um reencontro com a Pedagogia do oprimido. $24^{\circ}$ ed. São Paulo/ Rio de Janeiro: Paz e Terra, 2018.

FREIRE, Paulo; NOGUEIRA, Adriano. Que fazer: Teoria e Prática em Educação Popular. $13^{\circ}$ ed. Petrópolis: Vozes, 2020.

FOUCAULT, Michel. Ética, Sexualidade, Política. Rio de Janeiro: Forense Universitária. Coleção Ditos \& Escritos, v. 5, 2006.

FOUCAULT, Michel. O corpo utópico, as heterotopias. São Paulo: N-1 Edições, 2013. 
FOUCAULT, Michel. Vigiar e punir: nascimento da prisão. Rio de Janeiro: Vozes, 2020.

GAIMAN, Neil. Deuses americanos: edição preferida do autor; tradução Leonardo Alves. 1 ed. Rio de Janeiro: Intrínseca, 2016.

GOMES, Marcel Maia, FERRERI, Marcelo, LEMOS, Flávia. O cuidado de si em Michel Foucault: um dispositivo de problematização do político no contemporâneo. Revista de Psicologia, v. 30, n. 2, p. 189-195, maio-ago., 2018.

GUEDES, Adrianne Ogêda. O corpo nosso de cada dia: corporeidade e formação de professores. Revista Teias, v. 19, n. 52, p. 304-315, jan/mar., 2018.

JARA, Oscar. Educação Popular para a pospandemia: Construindo os inéditos-viáveis. 2020.

KRENAK, Ailton. O amanhã não está à venda. São Paulo: Schawarzc S.A, 2020.

LARROSA, Jorge. Notas sobre a experiência e o saber de experiência. Rev. Bras. Educ. [online], n. 19, p. 20-28, 2002.

LONGAREZI, Andrea Maturano; SILVA, Jorge Luiz da. Pesquisa-Formação: um olhar para sua constituição conceitual e política. Revista Contrapontos. v.13, n. 3, p. 214-225. Set/Dez, 2013.

OLIVEIRA, Wallace Araujo de. O desafio de estar e ser corpo. Revista Tropel, ed. 1, p. 210-212, jan./2021.

PERISSÉ, Gabriel. Estética \& Educação. Belo Horizonte: Autêntica Editora, 2009

SANTOS, Boaventura de Sousa. A cruel pedagogia do vírus. Coimbra: Edições Almedina, S.A, 2020.

VIANNA, Angel e CASTILHO, Jacyan. Percebendo o corpo: corpo que fala dentro e fora da Escola. Rio de Janeiro: DP\&A, 2002. 